\title{
POLA LORONG GUA DAN SPELEOGENESIS PADA SISTEM PERGUAAN GESING-JLAMPRONG-SINDEN KARST GUNUNGSEWU
}

\author{
Oleh: \\ Arif Ashari \\ Jurusan Pendidikan Geografi FIS UNY \\ ariecarstensz@gmail.com
}

\begin{abstract}
Abstrak
Penelitian ini dilakukan pada sistem perguaan Gesing-Jlamprong-Sinden yang berada di kawasan Karst Gunungsewu, Kabupaten Gunungkidul dengan tujuan untuk: (1) mengetahui pola lorong dan kenampakan speleogen-speleothem dalam gua, (2) mengetahui faktor-faktor yang mengendalikan speleogenesis, (3) merekonstruksi proses perkembangan gua. Penelitian ini menggunakan metode deskriptif. Data dikumpulkan dengan cara observasi, studi pustaka, dan dokumentasi. Dalam observasi dilakukan pengamatan dan pengukuran variabel lorong gua. Analisis dilakukan secara deskriptif dengan memperhatikan aspek-aspek geomorfologi, didukung dengan penalaran sebabakibat. Hasil penelitian menunjukkan Gua Gesing-Jlamprong-Sinden memiliki lorong utama tunggal dengan tipe lorong rectangular, eliptical, cayon, initial canyon, dan joint passage. Kenampakan dalam gua didominasi oleh speleogen. Karakteristik lorong dan kenampakan dalam gua tidak terlepas dari pengaruh faktor pengontrol speleogenesis, antara lain struktur geologi, topografi, litologi, dan hidrologi. Perkembangan Gua GesingJlamprong-Sinden dapat dirangkum dalam tiga tahap sejak akhir pleistosen masingmasing ditandai oleh pengangkatan disertai pembentukan kekar batugamping, perkembangan lorong oleh aliran freatik, serta perkembangan teras gua dan runtuhan langit-langit gua.
\end{abstract}

Kata kunci: speleogenesis, gua karst, lorong gua, perkembangan gua

\section{SPELEOGENESISAND THE PATTERN OF CAVE TUNNELS IN THE CAVE SYSTEM OF GESING-JLAMPRONG-SINDEN AT KARST AREA OFGUNUNGSEWU}

\begin{abstract}
The research was conducted in the cave system of Gesing-Jlamprong-Sinden located in the Karst area of Gunungsewu, Gunungkidul. This research aims to: (1) know the patterns of cave tunnel and the appearance speleogen-speleothem in the cave, (2) know the factors that control speleogenesis, (3) reconstruct the process of cave development. This research employs descriptive method. The data were collected through observation, library research, and documentation. The observation aims to measure the variables of cave tunnels. The analysis was performed descriptively by considering the aspects of geomorphology and employing cause and effect logic. The research findings show that Gesing-Jlamprong-Sinden caves have one main tunnel. The types of cave tunnels are rectangular, eliptical, cayon, initial canyon, and joint passage. The appearance of the cave is dominated by speleogen. The characteristics of cave tunnels and the appearance of the cave are affected by speleogenesis factors such as geological structure, topography, lithology, and hydrology. The development of Jlamprong - Sinden-Gesing
\end{abstract}


cave can be summarized in three stages i.e. each cave is marked by raising and forming strong limestone since the late of Pleistocene; the development of cave tunnels by freatik flow; and the development of caves' terrace and ruins of the cave's ceiling.

Keywords: speleogenesis, cavern, cave tunnel, cave development.

\section{Pendahuluan}

Gua merupakan suatu lorong yang terbentuk secara alami pada batuan yang berperan sebagai saluran air yang menghubungkan antara titik masuk air (aliran ke bawah permukaan) dan titik keluar. Ukuran lorong tersebut bervariasi dari $5 \mathrm{~mm}$ hingga ukuran besar. Ukuran minimum yang dapat dikatakan sebagai gua kurang lebih 0,3 meter sedangkan ukuran yang lebih kecil disebut protocave (Gillieson 1996). Oleh karena batasan tersebut secara sederhana timbul istilah gua merupakan rongga alamiah pada batuan yang dapat dimasuki manusia (Ford dan Williams, 2007; Goudie, 2004; Gillieson, 1996). Kebanyakan gua berkembang pada batugamping dan batuan karbonat lainnya pada bentanglahan karst. Gua karst pada umumnya tidak merupakan fenomena tunggal melainkan suatu sistem perguaan dimana gua satu dengan yang lain saling berhubungan (Worosuprodjo, 1996).

Keberadaan gua-gua karst merupakan indikator telah berkembangnya bentuklahan karst. Pembentukan gua terjadi oleh berlangsungnya proses pelarutan dan pelebaran celah-celah retakan batugamping. Proses ini berlangsung dalam waktu sangat lama di bawah kendali berbagai faktor, antara lain litologi batugamping, struktur geologi, topografi regional, serta kondisi hidrologi wilayah tersebut. Kombinasi dari pengaruh berbagai faktor ini menyebabkan morfologi gua yang terbentuk berbeda antara satu dengan lainnya. Melalui kajian speleogenesis dan morfologi gua, dapat dideskripsikan rekam jejak perkembangan gua dan faktor yang mempengaruhinya. Kajian ini bermanfaat untuk mengetahui kondisi lingkungan sekitar kaitannya dengan perkembangan bentuklahan. Selain itu kajian mengenai perkembangan gua sangat penting untuk interpretasi kondisi hidrologi dan geomorfologi kawasan karst, memprakirakan produksi akuifer, migrasi kontaminan, dan stabilitas tanah dan batuan dasar (Palmer, 1991).

Kompleks Gua Gesing-Jlamprong-Sinden terletak di Kecamatan Semanu, Kabupaten Gunungkidul, merupakan salah satu kompleks gua di wilayah tengah Karst Gunungsewu. Kompleks gua ini terdiri dari tiga gua yang saling berhubungan membentuk sistem perguaan. Walaupun berada pada satu kompleks, masing-masing dari ketiga gua ini memiliki karakteritsik morfologi yang spesifik. Diduga perkembangan gua terpengaruh oleh kombinasi berbagai faktor sekaligus. Kajian speleogenesis bermanfaat untuk mendeskripsikan pengaruh faktor-faktor yang mengendalikan perkembangan gua, tahap demi tahap perkembangan gua, serta memberikan berbagai informasi mengenai kondisi fisik gua untuk mendukung pengembangan pariwisata oleh masyarakat sekitar. 


\section{Metode Penelitian}

Penelitian ini menggunakan metode deskriptif dengan pendekatan keruangan dan kelingkungan. Data yang dikumpulkan meliputi data primer dan data sekunder. Data primer berupa hasil pengukuran dan pengamatan lapangan mengenai: (1) morfologi lorong gua, (2) speleogen dan speleothem, (3) keberadaan kekar, topografi, dan kondisi hidrologi wilayah sekitar gua. Data sekunder meliputi: (1) kondisi geologi dan geomorfologi regional diperoleh dari interpretasi peta geologi, peta rupabumi indonesia, dan sumber pustaka, (2) informasi mengenai usia dan tahap-tahap perkembangan karst gunungsewu diperoleh dari sumber pustaka. Pengumpulan data dilakukan dengan cara observasi langsung, studi pustaka, dan dokumentasi. Observasi langsung mengacu pada survei geomorfologi dengan memperhatikan aspek morfologi dan morfogenesa. Jenis data dan metode pengumpulannya ditunjukkan oleh Tabel 1.

Tabel 1. Jenis data dan teknik pengumpulan data

\begin{tabular}{|c|c|c|}
\hline Jenis data & $\begin{array}{c}\text { Teknik } \\
\text { pengumpulan data }\end{array}$ & Instrumen/sumber data \\
\hline \multicolumn{3}{|c|}{ Variabel lorong gua: } \\
\hline 1. Panjang dan arah lorong & Observasi & kompas, roll meter, yallon \\
\hline 2. Lebar lorong & Observasi & kompas, roll meter, yallon \\
\hline 3. Tinggi atap & Observasi & kompas, roll meter, yallon \\
\hline 4. Kemiringan dasar lorong & Observasi & Klinometer, yallon \\
\hline 5. Speleogen dan Speleothem & Observasi & Lembar observasi \\
\hline \multicolumn{3}{|c|}{ Variabel speleogenesis: } \\
\hline $\begin{array}{l}\text { 1. } \begin{array}{l}\text { Kondisi geologi dan } \\
\text { geomorfologi regional }\end{array}\end{array}$ & $\begin{array}{l}\text { Studi pustaka dan } \\
\text { dokumentasi }\end{array}$ & $\begin{array}{l}\text { Tjia (2013), Tjia (2011), } \\
\text { Haryono (2011), Haryono (2008), } \\
\text { Brahmantyo (2011), Bemmelen } \\
\text { (1949), Pannekoek (1949) }\end{array}$ \\
\hline 2. Keberadaan kekar & Observasi & GPS, kompas, lembar observasi \\
\hline 3. Kondisi hidrologi & Observasi & Lembar observasi \\
\hline 4. Kondisi topografi & Observasi & GPS, kompas, klinometer \\
\hline
\end{tabular}

Data yang diperoleh selanjutnya dianalisis secara deskriptif dengan memperhatikan aspek-aspek dan konsep dasar geomorfologi serta metode penalaran sebab-akibat. Untuk mencapai tujuan penelitian yang pertama dilakukan analisis data lapangan dengan memperhatikan aspek morfologi dan morfogenesa. Hasil analisis ditampilkan dalam peta lorong gua yang diproduksi dengan perangkat lunak survex dan coreldraw 14. Selanjutnya untuk mencapai tujuan penelitian yang kedua dan ketiga analisis deskriptif dilakukan dengan metode penalaran sebab akibat, yaitu dengan mengidentifikasi morfologi gua yang terbentuk sebagai hasil proses perkembangan gua dimana proses tersebut dikendalikan oleh berbagai faktor pengontrol perkembangan gua. 


\section{Hasil Penelitian dan Pembahasan \\ Daerah Penelitian}

Kompleks Gua Gesing-Jlamprong-Sinden terletak di Dusun Semuluh Lor, Desa Ngeposari, Kecamatan Semanu, Kabupaten Gunungkidul. Pintu masuk Gua Gesing terletak pada koordinat 454456 MT dan 9114597 MU, pintu masuk Gua Jlamprong yang sekaligus merupakan akhir lorong Gua Gesing teretak pada koordinat 464484 MT dan $9114437 \mathrm{MU}$, sedangkan pintu masuk Gua Sinden yang sekaligus akhir lorong Gua Jlamprong terletak pada koordinat 464667 MT dan 9113963 MU. Gua sinden hanya ditelusuri di sekitar pintu masuknya saja sebagai bagian akhir dari kegiatan penelusuran.

Panjang keseluruhan lorong gua yang dikaji 774,9 meter yang terdiri dari lorong Gua Gesing sepanjang 193,17 meter dari Gua Gesing ke Gua Jlamprong, serta lorong Gua Jlamprong sepanjang 581,73 meter dari Gua Jlamprong ke Gua Sinden. Bagian akhir penelusuran di Gua Sinden terletak pada perbatasan antara Desa Ngeposari, Kecamatan Semanu dengan Desa Gombang, Kecamatan Ponjong. Kompleks gua ini terletak pada ketinggian 150 - 230 mdpal dengan kemiringan lereng 2 - 26 \% (Widyarmoko, 2013).

Berdasarkan pembagian wilayah fisiografi oleh Pannekoek (1949) kompleks Gua Gesing-Jlamprong-Sinden terletak pada perbatasan antara Basin Wonosari dengan Perbukitan Karst Gunungsewu. Daerah ini tersusun atas batugamping Neogen (Miosen Tengah hingga Pliosen Atas) yang disebut sebagai Formasi Wonosari-Punung (tmwp) (Haryono, 2011) dan secara spesifik merupakan peralihan antara batugamping berlapis yang mendominasi basin wonosari di sebelah utara-barat daya dengan batugamping terumbu yang mendiminasi ke arah selatan. Curah hujan rata-rata selama sepuluh tahun antara tahun 2002 hingga 2011 sebesar 956,3 mm dengan hujan maksimum terjadi pada bulan Desember hingga Februari (Widyarmoko, 2013).

\section{Pola Lorong dan Kenampakan dalam Gua}

Myloire dan Carew (2003) membedakan gua yang terbentuk di daerah berbatuan karbonat menjadi tiga macam yaitu pit cave, phreatic cave, dan fracture cave. Berdasarkan klasifikasi tersebut, Gua Gesing, Jlamprong, dan Sinden masing-masing memiliki tipe yang berbeda. Gua Gesing bertipe fracture cave yaitu terbentuk oleh karena pelebaran retakan pada perlapisan batugamping. Gua Jlamprong bertipe phreatic cave dengan ciri mulut gua lebar dengan kedudukan horizontal, terbentuk karena terjadi pelarutan batugamping oleh aliran airtanah. Lebih khusus Gua Jlamprong termasuk dalam phreatic cave jenis banana hole. Adapun Gua Sinden termasuk dalam kategori pit cave dengan ciri mulut gua menurun dari permukaan lahan dengan kemiringan terjal. Tipe ini terbentuk oleh ekskavasi aliran vadose ketika menuju muka airtanah. Karena terbentuk oleh kerja aliran vadose, pit cave sering disebut juga sebagai vadose cave. Perhatikan Gambar 1 berikut ini. 

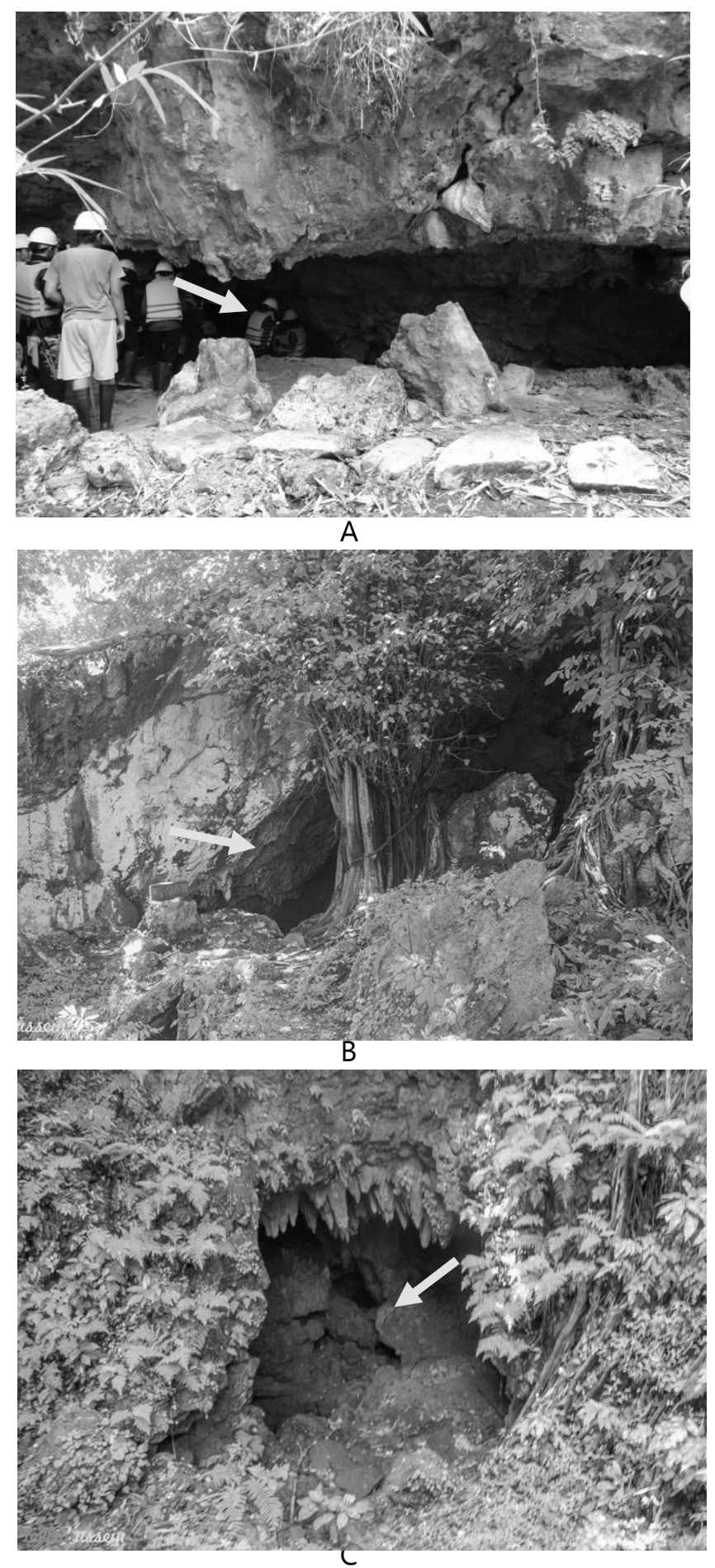

Gambar 1. Kenampakan pada pintu masuk gua, (A) Gua Gesing tipe fracture cave, (B) Gua Jlamprong tipe phreatic cave, (C) Gua Sinden tipe pit cave.

Lorong gua pada kompleks Gua Gesing-Jlamprong-Sinden menunjukkan pola sederhana dengan hanya memiliki satu lorong utama. Palmer (1991) memberikan istilah 
single-passage caves untuk gua dengan pola lorong semacam ini, sedangkan Frumkin dan Fischhendler (2005) menggunakan istilah chamber caves. Menurut Palmer (1991) single passage caves adalah bentuk permulaan yang dalam perkembangannya dapat berubah menjadi berbagai pola lainnya. Percabangan lorong yang dijumpai pada kompleks Gua Gesing-Jlamprong-Sinden umumnya masih berupa protocave. Dengan memperhatikan pengaruh dari bidang perlapisan dan keberadaan kekar yang terdapat di kompleks Gua Gesing-Jlamprong-Sinden, diduga pada masa mendatang tipe lorong single-passage cave dapat berkembang menjadi branchwork caves.

Lorong tunggal pada kompleks Gua Gesing-Jlamprong-Sinden memiliki variasi di berbagai segmen lorong. Pada awal penelusuran dari pintu masuk Gua Gesing hingga Gua Jlamprong lorong gua berpola sinous passage. Pola tersebut ditandai oleh kelokankelokan seperti meander di permukaan. Perkembangan lorong pada segmen ini belum terpengaruh oleh keberadaan kekar. Pada segmen selanjutnya antara pintu masuk Gua Jlamprong hingga Gua Sinden pola lorong lebih bervariasi yang dimulai dari linear passage dengan bentuk lurus, kemudian sinous passage, dan kembali linear passage menjelang akhir penelusuran. Pola ini menunjukkan adanya pengaruh kekar dalam perkembangan lorong gua. Pola lorong merupakan variabel morfologi gua yang dapat diidentifikasi dari observasi lapangan dan peta gua dengan kenampakan plan view (tampak samping kiri-kanan). Peta lorong gua Gesing-Jlamprong-Sinden ditunjukkan oleh Gambar 2 dan Gambar 3.

Walaupun memiliki pola lorong yang relatif sederhana, namun tipe lorong di kompleks Gua Gesing-Jlamprong-Sinden secara extended view (tampak atas bawah) cukup bervariasi. Hal ini disebabkan oleh kompleksitas faktor yang mempengaruhi perkembangan tipe lorong antara lain aliran bawah permukaan, aliran vadose, bidang perlapisan batugamping, dan keberadaan kekar. Pada awal penelusuran dijumpai tipe rectangular passage yaitu lorong dengan bentuk mendatar dan sudut-sudut tajam di bagian tepi. Lorong semacam ini terbentuk karena pengaruh perlapisan batugamping. Selanjutnya mendekati akhir penelusuran gua gesing dijumpai tipe eliptical passage, yang mengindikasikan erosi oleh aliran bawah permukaan sudah mulai bekerja intensif. Pada segmen Gua Jlamprong ke Gua Sinden dijumpai tipe eliptical passage, canyon dengan bentuk meninggi dan lantai gua berundak, gorge shaped passage dengan adanya erosi dasar saluran tetapi belum menghasilkan lantai berundak, dan joint passage dengan bentuk meninggi menjelang akhir penelusuran. Berbagai tipe lorong gua yang dijumpai ditunjukkan oleh Gambar 4.

Kenampakan dalam gua didominasi oleh speleogen daripada speleothem. Hal ini disebabkan oleh karena aliran sepanjang muka air tanah sangat dominan dan menyebabkan erosi. Bagian hulu Gua Gesing terhubung langsung dengan sungai permukaan sehingga apabila terjadi hujan, sistem perguaan Gesing-Jlamprong-Sinden akan segera menjadi saluran drainase. Aliran vadose yang mempengaruhi perkembangan speleothem dijumpai setempat-setempat. Speleogen yang dijumpai antara lain solution notch, solution pocket, pothole, dan scallop. Adapun speleothem yang dijumpai antara lain stalaktit, stalagmit, dan pilar. Runtuhan (breakdown) banyak dijumpai dengan 
berbagai ukuran yang menunjukkan lemahnya bidang perlapisan batugamping. Berbagai kenampakan speleogen dan speleothem pada lorong gua ditunjukkan oleh Gambar 5. 


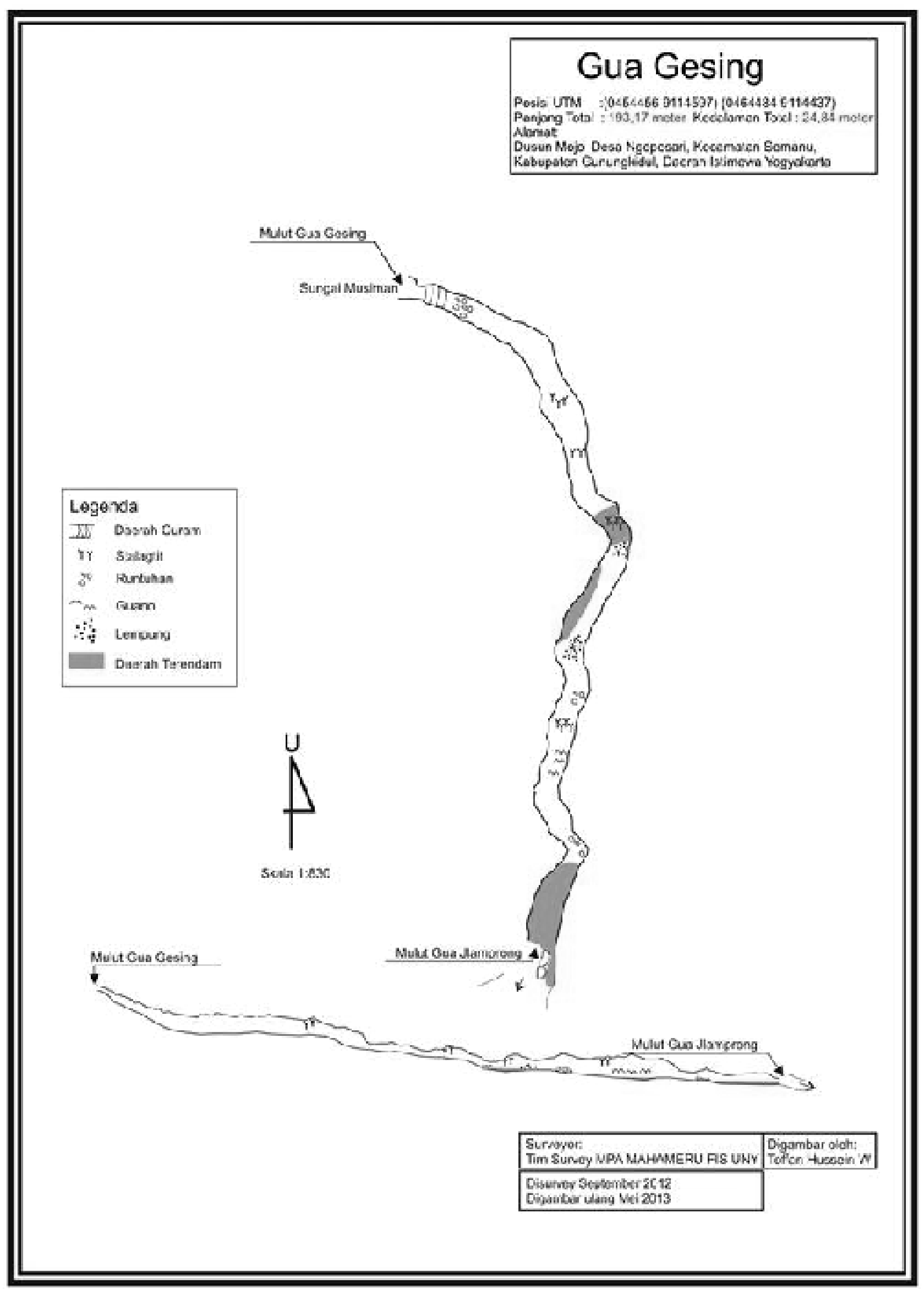

Gambar 2. Peta lorong Gua Gesing-Jlamprong (Widyarmoko, 2013 dengan modifikasi) 


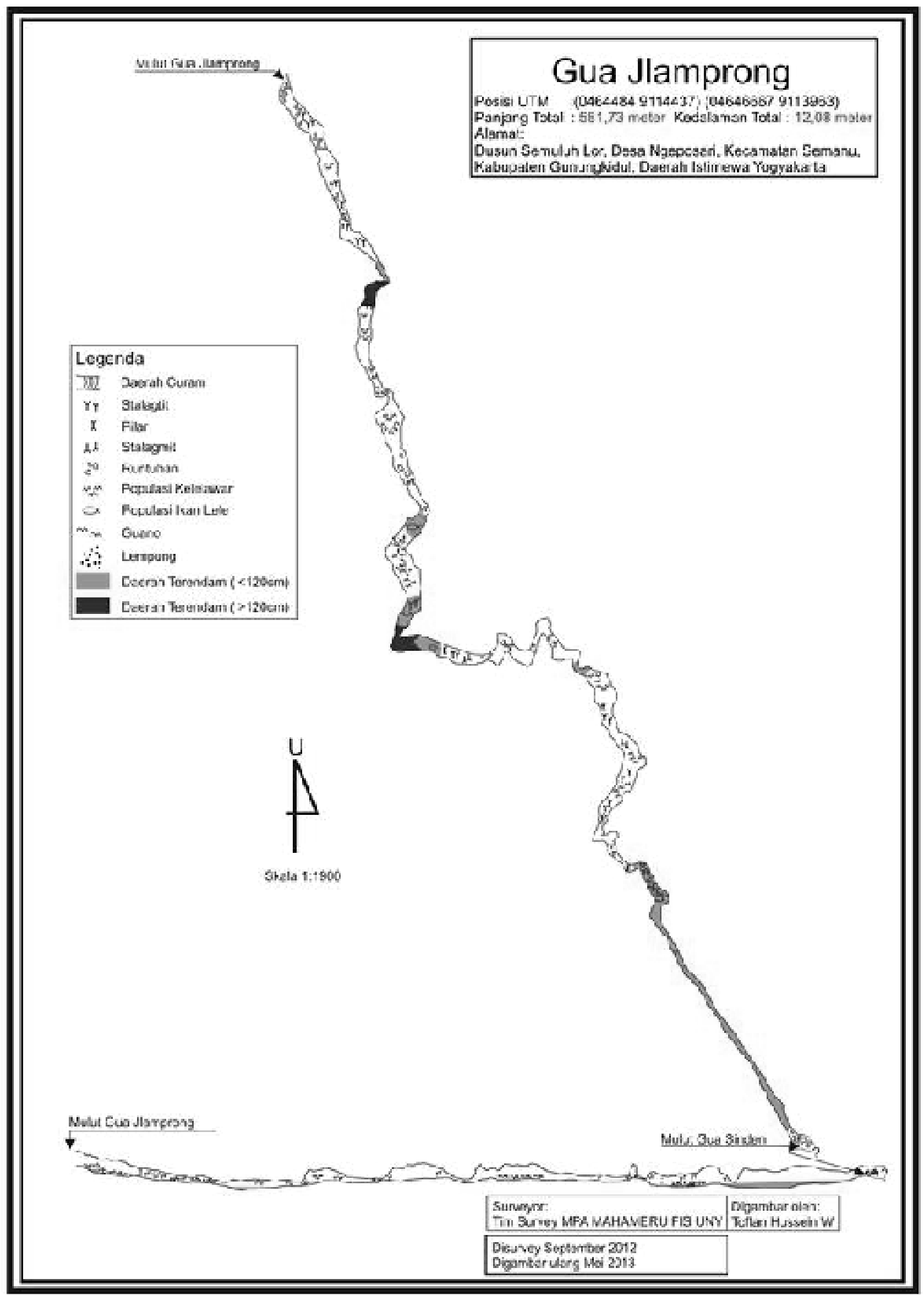

Gambar 3. Peta lorong Gua Jlamprong-Sinden (Widyarmoko, 2013 dengan modifikasi) 

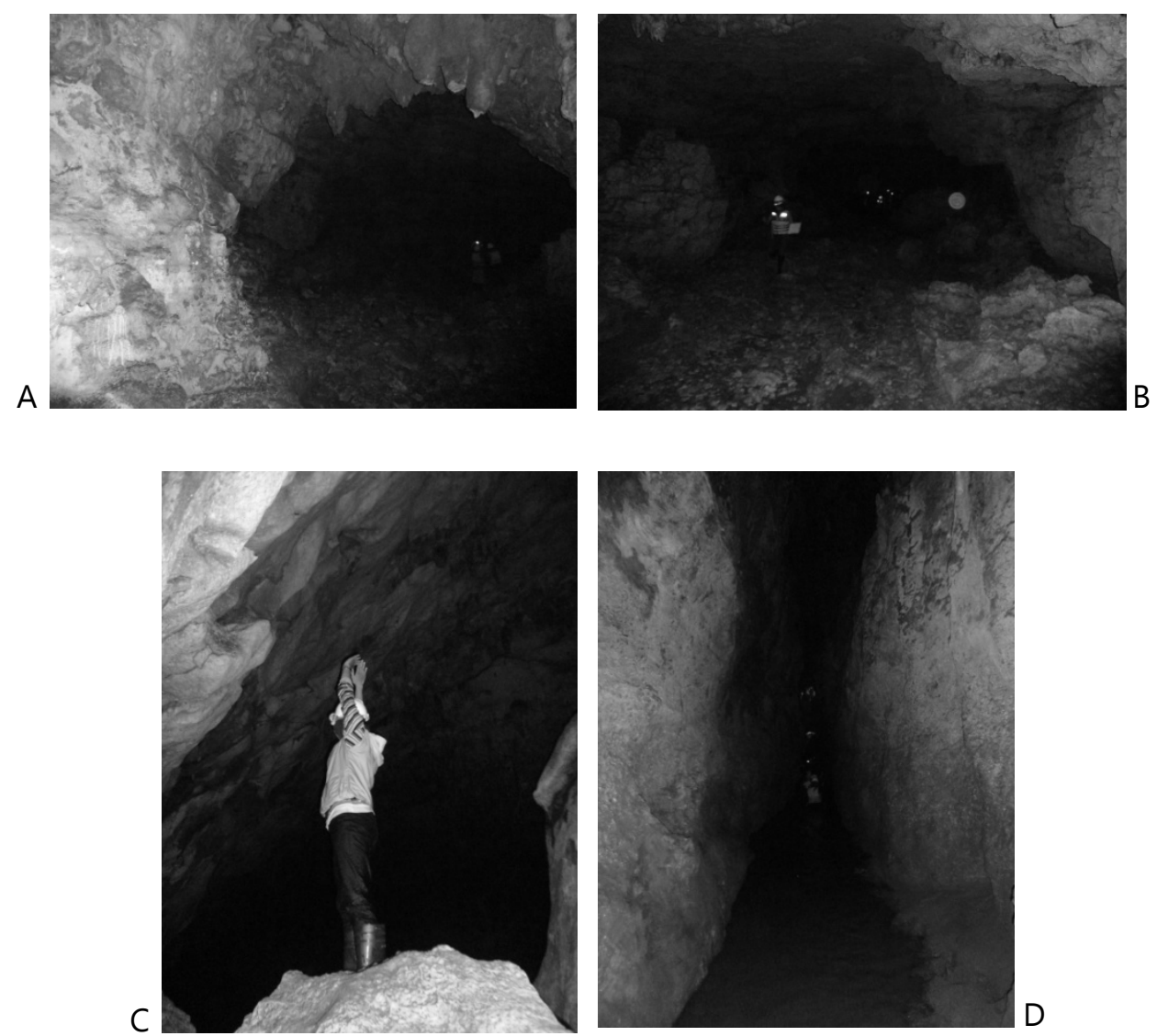

Gambar 4. Tipe-tipe lorong pada Gua Gesing-Jlamprong-Sinden. A: eliptical passage, B: rectangular passage, C: Canyon, D: Joint passage
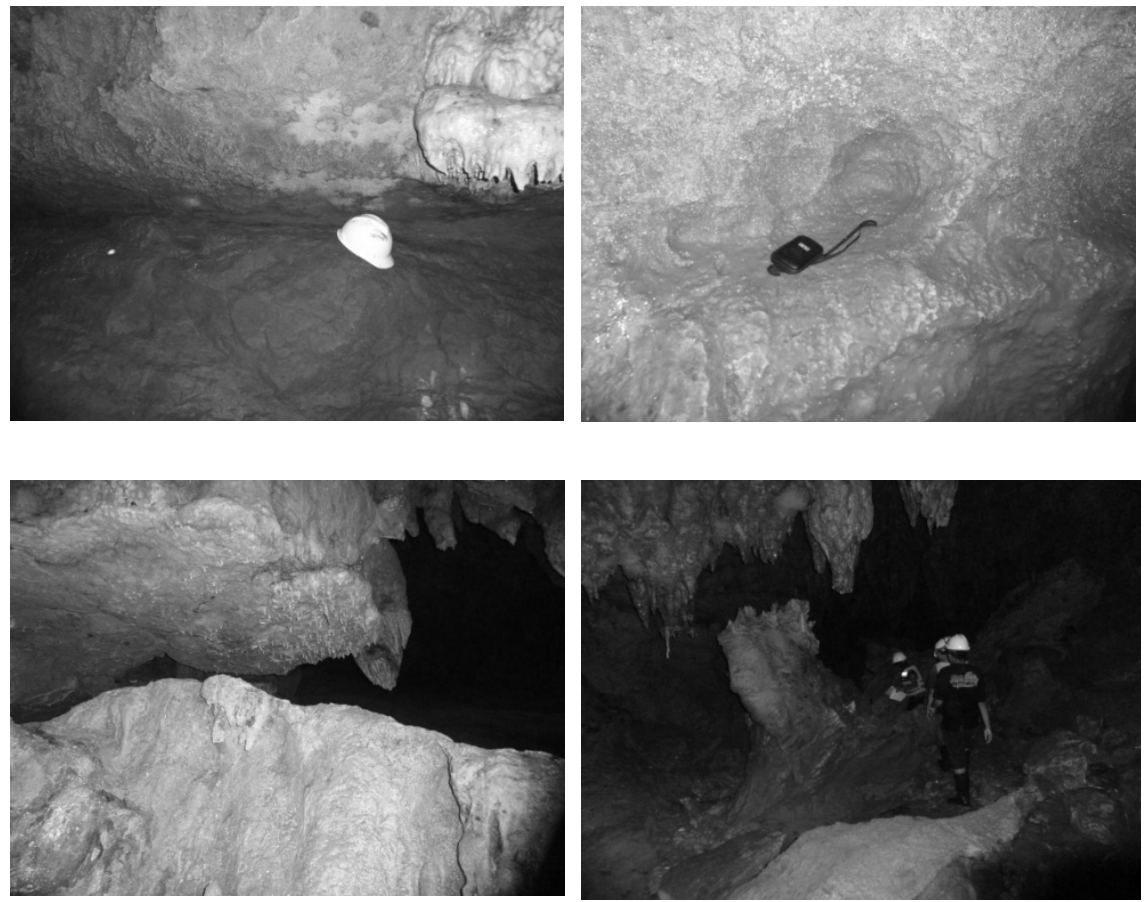

Gambar 5. Kenampakan speleogen dan speleothem pada Gua Gesing-Jlamprong-Sinden. Searah jarum jam dari kiri atas: solution notch, scallop, stalaktit dan stalagmit, breakdown. 


\section{Faktor-faktor pengontrol speleogenesis sistem perguaan Gesing-Jlamprong-Sinden}

Pembentukan dan perkembangan gua dipengaruhi oleh berbagai macam faktor. Bahkan morfologi gua yang terbentuk merupakan hasil kombinasi kerja berbagai faktor tersebut, oleh karenanya morfologi satu gua dengan gua lainnya senantiasa berbeda. Gillieson (1996) menyebutkan beberapa faktor yang mempengaruhi speleogenesis yaitu struktur geologi, litologi, kondisi kimia, paleokarst, kondisi hidrologi, iklim, dan waktu. struktur geologi, litologi, kondisi kimia merupakan faktor yang berpengaruh pada stadium awal pembentukan gua, sedangkan paleokarst, kondisi hidrologi, iklim, dan waktu pengaruhnya nampak dalam perkembangan gua selanjutnya.

Kontrol struktur geologi dalam perkembangan lorong gua Gesing-Jlamprong-Sinden secara umum ditunjukkan oleh pengaruh bidang perlapisan dan kekar. Bidang perlapisan menghasilkan lorong gua dengan bentuk melebar atau berkembang secara horizontal sedangkan kekar menghasilkan lorong gua dengan bentuk meninggi atau berkembang secara vertikal. Struktur geologi dapat dikatakan sebagai faktor yang mempengaruhi bentuk gua pada tahap permulaan, kemudian bentuk tersebut dalam perkembangannya termodifikasi oleh karena pengaruh faktor lainnya. Pengaruh bidang perlapisan terutama dijumpai di Gua Gesing. Beberapa lorong yang belum termodifikasi dapat dikenali dengan bentuk rectangular passage, sementara yang termodifikasi oleh aliran menghasilkan bentuk lorong yang berkelok seperti meandering sungai permukaan. Sementara pengaruh kekar nampak jelas dijumpai di Gua Jlamprong menjelang akhir penelusuran menuju Gua Sinden, yaitu dengan bentuk joint passage dengan erosi di dasar saluran. Peta lorong gua yang disajikan pada Gambar 2 dan 3 menunjukkan bahwa segmen Gua Gesing ke Gua Jlamprong memiliki kelokan yang lembut sementara pada segmen Gua Jlamprong ke Gua Sinden kelokan lebih tajam dan cenderung menyudut. Kelokan tersebut menurut Palmer (1991) merupakan salah satu kontrol bidang perlapisan dan retakan terhadap perkembangan pola lorong gua. Secara umum arah lorong gua cenderung mengarah ke tenggara oleh karena pengaruh keberadaan kekar wilayah tersebut dengan arah barat daya tenggara, termasuk diantaranya mempengaruhi perkembangan karst labirin di bagian selatan kompleks gua ini (Haryono dan Day, 2004; Haryono, 2011; Tjia, 2013); Kusumayudha, 2005).

Speleogenesis Gua Gesing-Jlamprong-Sinden juga sangat dipengaruhi oleh topografi regional. Karst Gunungsewu memiliki kemiringan rata-rata 2\% (Haryono, 2011) atau maksimum 26\% (Brahmantyo, 2011) ke arah selatan. Kondisi tersebut mempengaruhi perkembangan lorong Gua Gesing-Jlamprong-Sinden yang semakin dalam ke arah hilir. Hal ini disebabkan oleh karena aliran freatik di sepanjang muka airtanah lebih dominan mempengaruhi perkembangan gua daripada aliran vadose sehingga perkembangan terjadi mengikuti kedudukan muka airtanah. Berdasarkan peta lorong gua pada gambar dengan pengamatan extended view diketahui terjadi penurunan lantai gua dari Gua Gesing ke Gua Jlamprong. Adapun dari Gua Jlamprong ke Gua Sinden penurunan tidak nampak signifikan tetapi daerah yang terendam semakin banyak dan semakin dalam. Diduga hal ini karena kemiringan yang berkurang menyebabkan aliran melambat dan memperbesar peluang untuk terjadinya erosi pada dasar saluran (Brahmantyo, 2011). Kemiringan terbentuk sejak awal pengendapan batuan karbonat di daerah Gunungsewu karena pergeseran blok-blok secara lateral maupun vertikal (Kusumayudha, 2005). Selain 
kemiringan, pengangkatan yang terjadi pada Karst Gunungsewu juga mempengaruhi perkembangan gua. Akibat pengangkatan terjadi penurunan muka airtanah sehingga lantai gua mengalami pendalaman. Bukti-bukti pengaruh pengangkatan adalah bekas aliran air pada dinding gua yang kedudukannya lebih tinggi dari rata-rata tinggi muka air pada lorong gua saat ini. Menurut Haryono (2013) pengangkatan berhubungan erat dengan perkembangan karst karena banyak kenampakan karst terbentuk dibawah pengaruh proses pengangkatan.

Kondisi hidrologi memiliki pengaruh penting dalam perkembangan gua karena faktor ini banyak memodifikasi bentukan yang terkontrol oleh kekar atau bidang perlapisan. Kompleks Gua Gesing-Jlamprong-Sinden berada pada perbatasan antara Karst Gunungsewu dengan Basin Wonosari. Oleh karena kedudukan tersebut banyak aliran permukaan dari basin wonosari yang masuk ke dalam gua sehingga perkembangan gua sangat terpengaruh oleh aliran freatik. Diduga faktor inilah yang menyebabkan speleogen lebih mendominasi kenampakan pada lorong gua. Faktor lain yang juga mempengaruhi speleogen adalah litologi batugamping. Litologi batugamping di wilayah ini adalah wackstone (Kusumayudha, 2005) termasuk tipe batugamping yang mudah terlarut sehingga mempercepat perkembangan gua. Wackstone termasuk dalam jenis batugamping berlapis. Porositas sekunder fasies batugamping ini rata-rata sebesar 14,29\% (Kusumayudha, 2005). Di wilayah ini, batugamping berapis tersusun dengan kedudukan horizontal yang berpengaruh terhadap bentuk dan arah lorong. Kondisi semacam ini juga terjadi di Karst Gombong Selatan (Brahmantyo, 2011). Adapun pada lorong Gua Gesing-Jlamprong-Sinden bukti-bukti pengaruh perlapisan batugamping terhadap speleogenesis adalah tipe lorong rectangular yang masih banyak belum termodifikasi oleh aliran dan sebab lain. Disamping itu terjadi runtuhan (Gambar 5) yang menambah luas lorong gua.

\section{Rekonstruksi Perkembangan Gua Gesing-Jlamprong-Sinden}

Dengan mencermati morfologi yang telah terbentuk dan pengaruh berbagai faktor pengontrol speleogenesis yang mempengaruhi pembentukan morfologi tersebut, dapat disimpulkan perkembangan Gua Gesing-Jlamprong-Sinden telah berlangsung cukup lama dan meliputi beberapa tahap perkembangan. Tahap demi tahap tersebut berlangsung sejalan dengan tahapan perkembangan Karst Gunungsewu secara umum.

Perkembangan lorong sistem perguaan Gesing-Jlamprong-Sinden dapat dirangkum dalam tiga tahap yang dimulai sejak akhir pleistosen. Tahap pertama terjadi bersamaan dengan pengangkatan teras marin ke tiga pada Karst Gunungsewu. Wilayah Gua GesingJlamprong-Sinden memiliki elevasi rata-rata 150 mdpal, sedikit lebih tinggi dari teras ke tiga Karst Gunungsewu dengan ketinggian rata-rata 112,5 mdpal. Teras ke dua berada pada ketinggian 137,5 mdpal sedangkan teras pertama pada ketinggian sekitar 300 mdpal (Haryono, 2011). Menurut Sutikno dan Tanudirdjo (2011) terdapat empat tahapan perkembangan Karst Gunungsewu yang masing-masing ditandai oleh kedudukan teras marin, tahap pertama terjadi pada akhir pliosen, tahap kedua pada awal pleistosen, tahap ketiga pada pertengahan pleistosen dan tahap keempat pada akhir pleistosen. Bersamaan dengan proses pengangkatan terbentuk retakan-retakan yang kemudian mengendalikan perkembangan gua. 
Sebelum pengangkatan teras ke tiga, lahan Gua Gesing-Jlamprong-Sinden berada sedikit di atas permukaan air yang menggenangi Basin Wonosari. Kedudukan tersebut menyebabkan percampuran antara air vadose yang telah jenuh kalsit dengan air yang terjebak pada basin wonosari menghasilkan air dengan agresivitas tinggi untuk melarutkan batugamping (Bogli, 1980 dalam Adji, 2010) membentuk gua pada wilayah peralihan yang dikenal sebagai flank margin cave (Myloire dan Carew, 2003). Agresivitas airtanah ini selanjutnya memperlebar lorong yang sebelumnya terbentuk pada bidang perlapisan dan kekar batugamping.

Tahap kedua mulai berlangsung setelah akhir pengangkatan yang menghasilkan teras ketiga Karst Gunungsewu. Bentuklahan pada masa ini sama dengan bentuklahan pada masa sekarang. Selain itu Basin Wonosari telah kehilangan genangannya karena telah didrainase secara intensif. Lorong gua yang telah terbentuk pada tahap sebelumnya pada tahap ini mulai mendapatkan input air dari Basin Wonosari sehingga perkembangan gua dikendalikan oleh aliran freatik. Hal ini dibuktikan oleh morfologi gua yang terbentuk di sepanjang aliran airtanah dan sedikit pengaruh dari aliran vadose. Air pada zona freatik memilliki tekanan hidrostatik yang tinggi sehingga mampu membentuk rongga-rongga termasuk pada wilayah dengan sedikit retakan (Surawan, 2010). Ekskavasi oleh aliran vadose dijumpai di Gua Sinden karena muka air tanah yang semakin dalam karena mengikuti perlapisan batugamping yang miring ke arah selatan.

Tahap ketiga masih berlangsung hingga saat ini, dipengaruhi oleh pengangkatan yang masih terus terjadi sehingga menyebabkan penurunan muka air tanah. Oleh karena penurunan tersebut maka di beberapa bagian terjadi pelarutan lanjut menghasilkan tingkatan pada lantai gua. Bukti-bukti pengangkatan juga dijumpai pada bekas muka airtanah di dinding lorong gua maupun pilar. Perkembangan lorong gua pada tahap ini juga dipercepat oleh terjadinya runtuhan pada langit-langit gua. Walaupun telah berkembang dalam waktu yang lama, namun morfologi Gua Gesing-Jlamprong-Sinden dengan lorong tunggal yang didominasi oleh speleogen menunjukkan bahwa gua ini masih berada pada tahap awal perkembangan (Palmer, 1991), perkembangan ke depan masih dapat terus berlanjut di bawah kendali berbagai faktor pengontrol speleogenesis. Tahap perkembangan sistem perguaan Gesing-Jlamprong-Sinden ditunjukkan oleh Gambar 6.

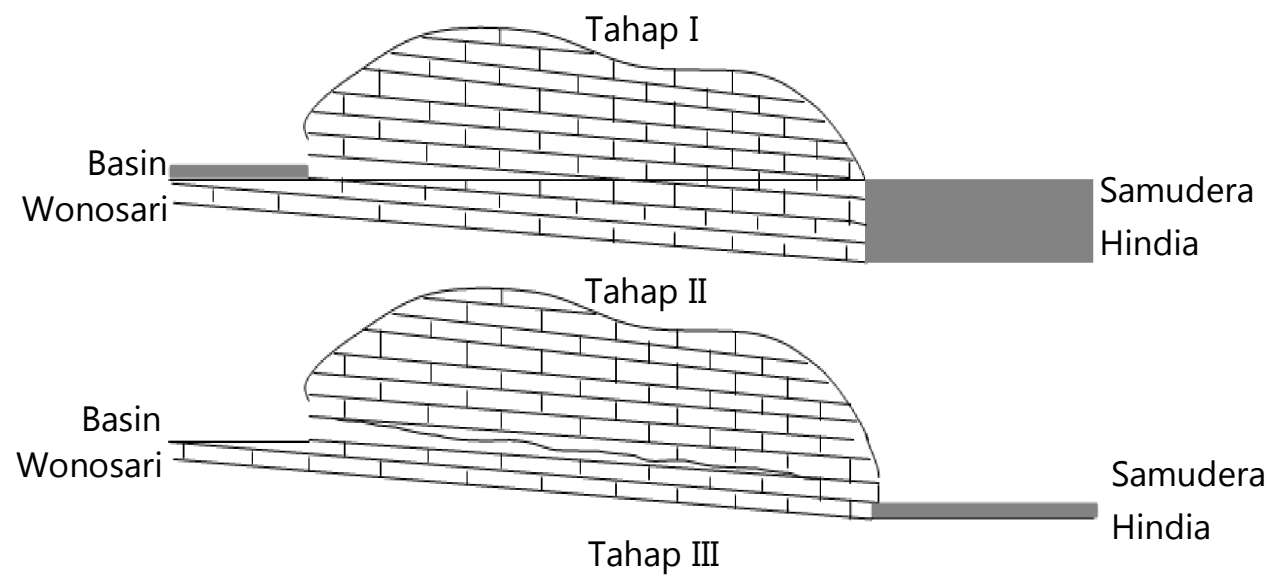




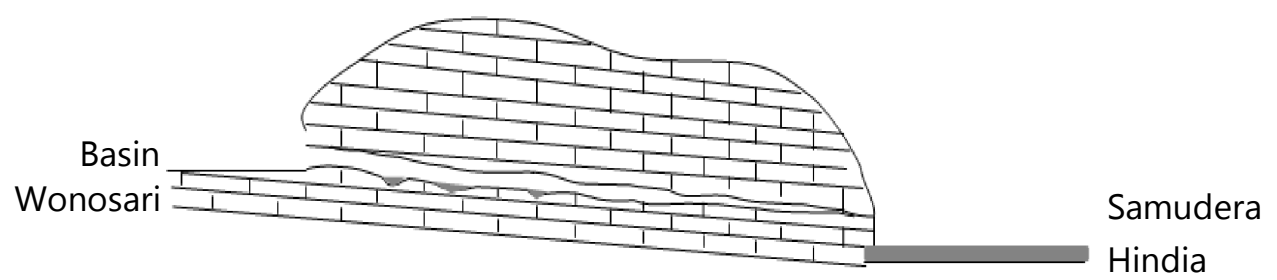

Gambar 6. Tahap-tahap perkembangan Karst Gunungsewu

\section{Kesimpulan}

Sistem perguaan Gesing-Jlamprong-Sinden telah cukup lama mengalami perkembangan, namun demikian lorong gua yang masih berupa lorong tunggal (singlepassage caves) menunjukkan bahwa sebenarnya sistem perguaan ini masih dalam tahap awal perkembangan. Pada masa mendatang lorong-lorong gua akan terus berkembang sehingga menjadi sistem lorong yang lebih rumit, terdiri dari banyak lorong yang bercabang dan saling berpotongan. Kenampakan dalam gua yang lebih didominasi oleh speleogen daripada speleothem disebabkan oleh karena aliran sepanjang muka air tanah sangat dominan dan menyebabkan erosi.Adapunaliran vadose yang mempengaruhi perkembangan speleothem dijumpai setempat-setempat.

Speleogenesis dipengaruhi oleh berbagai faktor yaitu struktur geologi berupa bidang perapisan batugamping dan bidang sesar-kekar, topografi, kondisi hidrologi, dan litologi. Perkembangan lorong sistem perguaan Gesing-Jlamprong-Sinden dapat dirangkum dalam tiga tahap yang dimulai sejak akhir pleistosen. Tahap pertama terjadi bersamaan dengan pengangkatan teras marin ke tiga pada Karst Gunungsewu.Tahap kedua mulai berlangsung setelah akhir pengangkatan yang menghasilkan teras ketiga Karst Gunungsewu.Tahap ketiga masih berlangsung hingga saat ini, dipengaruhi oleh pengangkatan yang masih terus terjadi sehingga menyebabkan penurunan muka air tanah. Fisiografi regional sangat berpengaruh dalam ketiga tahap perkembangan ini.

\section{Daftar Pustaka}

Adji, T.N. 2010. Variasi Spasial Temporal Hidrogeokimia dan Sifat Aliran Untuk Karakterisasi Sistem Karst Dinamis di Sungai Bawah tanah Bribin, Kabupaten Gunungkidul, DIY. Disertasi. Program Pascasarjana Universitas Gadjah Mada.

Brahmantyo, B. 2011. Menjelajah Ribuan Bukit Karst di Gunungsewu.Ekspedisi Geografi Indonesia Karst Gunungsewu 2011.Pusat Survei Suberdaya Alam Darat, Bakosurtanal.

Myloire, J.E. dan Carew, J.L. 2003 Karst Development on Carbonate Island. Speleogenesis and Karst Akuifer 1 (2): 1-21.

Ford, D. dan Williams, P. 2007. Karst Hydrogeology and Geomorphology. Sussex: John Wiley and Sons.

Frumkin, A. dan Fischhendler, I. 2005. Morphometry and Distribution of Isolated Caves as a Guide For Phreatic and Confined Paleohydrological Conditions. Geomorphology 67: 457-471.

Gillieson, D. 1996. Caves Process Development and Management. Cambridge: Blacwell Publisher.

Goudie, A.S (ed). 2004. Encyclopedia of Geomorphology, Volume 1. London: Routledge. 
Haryono, E. 2011. Introduction Gunungsewu Karst Java-Indonesia. Field Guide Asian Trans Disciplinary Karst Conference 2011.

Haryono, E. dan Day, M. 2004. Landform Differentiation Within the Gunung Kidul Kegelkarst, Java, Indonesia. Journal of Cave and Karst Studies 66 (2): 62-69.

Haryono, E. 2013. Uplift Evidence From Karst Morphology: Preliminary Evidence From Blambangan Peninsula Karst, Indonesia. 16th International Congress of Speleology Czech Republic, Brno 21-28 2013. Dalam www.lib.geo.ugm.ac.id. Diakses tanggal 15 Juni 2013.

Kusumayudha, S.B. 2005. Hidrogeologi Karst dan Geometri Fraktal di Daerah Gunungsewu.Yogyakarta: Adicita

Palmer, A.N. 1991. Origin and Morphology of Limestone Caves. Geological Society of America Bulletin 103: 1-21.

Pannekoek, A.J. 1949. Outline of The Geomorphology of Java. Leiden: E. J. Brill.

Surawan, C. 2010. Kajian Speleogenesis dan Karakteristik Morfologi Lorong Sistem Perguaan Kiskendo - Soemitro. Skripsi. Fakultas Geografi Universitas Gadjah Mada.

Sutikno dan Tanudirdjo, Daud. 2011. Geoarchaeological Study of Gunungsewu Karst As Model for Environmental Conservation. Dalam Haryono, E., Adji, T.N., dan Suratman (ed). 2011. Prosiding Seminar Asian Trans Disciplinary Karst Conference. Yogyakarta 7-10 Januari 2011.

Tjia, H.D. 2013. Morphostructural Development of Gunungsewu Karst, Jawa Island. Indonesian Journal of Geology 8 (2): 75-88.

Widyarmoko, T.H. 2013. Potensi Gua Gesing-Jlamprong-Sinden untuk Pengembangan Ekowisata Minat Khusus di Desa Ngeposari, Kecamatan Semanu, Kabupaten Gunungkidul. Skripsi. Fakultas Ilmu Sosial. Universitas Negeri Yogyakarta.

Worosuprodjo, S. 1996. Potensi dan Pengelolaan Gua di Provinsi Daerah Istimewa Yogyakarta. Majalah Geografi Indonesia. 10 (18): 59-65. 
|| Speleogenesis dan Pola Lorong Gua Pada Sistem Perguaan Gesing-Jlamprong-Sinden, Karst Gunungsewu 